\title{
Endophytic colonization of rice (Oryza sativa L.) by the diazotrophic bacterium Burkholderia kururiensis and its ability to enhance plant growth
}

\author{
KATHERINE A. MATTOS ${ }^{1 \dagger}$, VANIA L.M. PÁDUA ${ }^{2 \dagger}$, ALEXANDRE ROMEIRO ${ }^{1 \dagger}$, LETICIA F. HALLACK ${ }^{1 \dagger}$, \\ BIANCA C. NEVES ${ }^{1}$, TECIA M.U. ULISSES ${ }^{1}$, CLAUDIA F. BARROS ${ }^{3}$, ADRIANE R. TODESCHINI ${ }^{1}$, \\ JOSÉ O. PREVIATO ${ }^{1}$ and LUCIA MENDONÇA-PREVIATO ${ }^{1}$ \\ ${ }^{1}$ Instituto de Biofísica Carlos Chagas Filho, Universidade Federal do Rio de Janeiro, \\ Centro de Ciências da Saúde, Cidade Universitária, Ilha do Fundão, 21944-970 Rio de Janeiro, RJ, Brasil \\ ${ }^{2}$ Instituto de Bioquímica Médica, Centro de Ciências da Saúde, Universidade Federal do Rio de Janeiro, \\ Cidade Universitária, Ilha do Fundão, 21944-970 Rio de Janeiro, RJ, Brasil \\ ${ }^{3}$ Laboratório de Botânica Estrutural, Instituto de Pesquisas Jardim Botânico do Rio de Janeiro, \\ Rua Jardim Botânico, 1008, Jardim Botânico, 22460-000 Rio de Janeiro, RJ, Brasil \\ Manuscript received on April 14, 2008; accepted for publication on May 27, 2008; \\ contributed by José O. Previato* and Lucia Mendonça Previato*
}

\begin{abstract}
Burkholderia kururiensis is a diazotrophic bacterium originally isolated from a polluted aquifer environment and presents a high level of similarity with the rice endophyte " $B$. brasilensis" species. This work assessed the ability of $B$. kururiensis to endophytically colonize rice plantlets by monitoring different tissues of root-inoculated plants for the presence of bacterial growth in different media, electron microscopy and by 16S rDNA analysis. Observations of roots, stems and leaves of inoculated rice plantlets by electron microscopy revealed B. kururiensis colonization predominantly on root hair zones, demonstrating endophytic colonization primarily through the endodermis, followed by spreading into xylem vessels, a possible pathway leading to aerial parts. Although indifferent for the bacterial growth itself, addition of a nitrogen source was a limiting factor for endophytic colonization. As endophytic colonization was directly associated to an enhanced plant development, production of phytohormone auxin/indole-3-acetic acid by B. kururiensis was assayed with transgenic rice plantlets containing an auxin-responsive reporter (DR5-GUS). Our findings suggest the ability of auxin production by plant-associated B. kururiensis which may have a stimulatory effect on plant development, as evidenced by activation of DR5-GUS. We hereby demonstrate, for the first time, the ability of $B$. kururiensis to endophytically colonize rice, promoting both plant growth and rice grain yield.
\end{abstract}

Key words: Burkholderia kururiensis, colonization, rice, diazotrophic bacterium, auxin.

\section{INTRODUCTION}

Burkholderia a phylogenetically well-defined genus which is remarkably diverse in view of its wide environmental distribution and its capabilities for biodegra-

\footnotetext{
*Member Academia Brasileira de Ciências

$\dagger$ These authors contributed equally to this study.

†Present address: Departamento de Pesquisa e Extensão, Centro Universitário Estadual da Zona Oeste, 21070-200 Rio de Janeiro, RJ, Brasil Correspondence to: Lucia Mendonça-Previato

E-mail: luciamp@biof.ufrj.br
}

dation of pollutants (Zhang et al. 2000, Goris et al. 2004, Wang et al. 2004), production of compounds with antimicrobial activity (el-Banna and Winkelmann 1998, Santos et al. 2004, Rosenblueth and MartinezRomero 2006) or promotion of plant growth (Baldani et al. 2000, Scarpella et al. 2003, Sessitsch et al. 2005, Chen et al. 2006). Burkholderia species may exhibit pathogenic and non-pathogenic interactions with plants, the later being through symbiotic or endophytic asso- 
ciations (Barraquio et al. 1997, Sevilla et al. 2001, Caballero-Mellado et al. 2004, Chen et al. 2006, Perin et al. 2006). Unlike legume-nodulating symbionts, endophytically associated species have developed intimate and mutually beneficial interactions with different parts of the plants, colonizing roots, stems and leaves. Those include B. vietnamiensis (Gillis et al. 1995, Govindarajan et al. 2008), B. unamae (Caballero-Mellado et al. 2004), B. tropica (Reis et al. 2004), "B. brasilensis" (Baldani et al. 1997), and B. phytofirmans (Sessitsch et al. 2005). Plant-growth capabilities so far observed during endophytic associations suggest that the production of phytohormones and/or fixation of atmospheric nitrogen could act as positive regulators of mechanisms that lead to the plant development (Muñoz-Rojas and Caballero-Mellado 2003, Pedraza et al. 2004).

B. kururiensis, a species isolated from a trichloroethylene-polluted aquifer environment (Zhang et al. 2000), and which association to plants has not been described to date, was shown capable of fixing atmospheric nitrogen comparable to "B. brasilensis" (Estrada-de los Santos et al. 2001), a species isolated from roots of rice plants growing in Brazil (Baldani et al. 1997). Further studies on sequence comparisons of amplified polymerase chain reaction $\operatorname{gln} B$, nifH, and 16S rDNA gene fragments of nitrogen-fixing Burkholderia species suggested a close phylogenetic and functional relationship between B. kururiensis and "B. brasilensis" (Marin et al. 2003); nevertheless, " $B$. brasilensis" is a species not officially validated (Caballero-Mellado et al. 2007). Therefore, a detailed investigation of a putative $B$. kururiensisplant association is of great interest, specially with rice, which is one the most important staple crop in the developing world (Barraquio et al. 1997, Kuklinsky-Sobral et al. 2004), since many studies have been focused on the search for natural diazotrophs that can possibly act as plant-growth promoting associative bacteria (Baldani et al. 2000, Biswas et al. 2000, Trân Van et al. 2000, Ciccillo et al. 2002, Compant et al. 2005, Muthukumarasamy et al. 2006, Rosenblueth and Martinez-Romero 2006, Govindarajan et al. 2008).

In the present study, we have investigated the importance of $B$. kururiensis during rice cultivation, by assessing its ability to establish an endophytic association with rice plants. Its potential as a plant-growth- promoting bacterium was clearly demonstrated along with the ability to endophytically colonize rice, under laboratory and greenhouse conditions. We investigated the production of bacterial auxin/indole-3-acetic acid (IAA), a reciprocal signaling molecule in plant-bacteria interactions. Based on electron microscopy observations we provided an insight about the route followed by $B$. kururiensis to colonize and spread through the rice plant tissues.

\section{MATERIALS AND METHODS}

\section{BACTERIAL STRAIN AND GROWTH CONDITIONS}

B. kururiensis, strain $\mathrm{KP}^{2} 3^{\mathrm{T}}$ (Zhang et al. 2000) isolated from an aquifer environment, was kindly provided by Dr. Yoichi Kamagata (National Institute of Bioscience and Human Technology, Agency of Industrial Science and Technology, Japan). "B. brasilensis" strain 130 isolated from the roots of rice plants growing in Brazil (Baldani et al. 1997) was obtained from the Culture Collection of Empresa Brasileira de Pesquisa Agropecuária (EMBRAPA, Rio de Janeiro, Brasil). Escherichia coli strain E 2348/69 (Levine et al. 1985) was from our culture collection. Bacteria were grown in liquid DYGS medium (Rodrigues Neto et al. 1986) at $28^{\circ} \mathrm{C}$ and shaken at $200 \mathrm{rpm}$ for $24 \mathrm{~h}$. Quantification of bacterial population in plant macerates was performed by colony forming units (CFU) on agar plates, using either DYGS medium or JMV medium (Reis et al. 2004). To investigate IAA production: B. kururiensis $\mathrm{KP} 23^{\mathrm{T}}$ was grown on nitrogen-free $\mathrm{MAZ}$ modified medium ( $\mathrm{g} / \mathrm{liter}$ ): $\mathrm{K}_{2} \mathrm{HPO}_{4} .3 \mathrm{H}_{2} \mathrm{O}, 6.0 ; \mathrm{KH}_{2} \mathrm{PO}_{4}, 4.0 ; \mathrm{MgSO}_{4} .7 \mathrm{H}_{2} \mathrm{O}, 0.2$; $\mathrm{NaCl}, 0.1 ; \mathrm{CaCl}_{2}, 0.02 ; \mathrm{FeCl}_{3} .6 \mathrm{H}_{2} \mathrm{O}, 0.01 ; \mathrm{H}_{3} \mathrm{BO}_{3}$, $0.0028 ; \mathrm{MnSO}_{4} . \mathrm{H}_{2} \mathrm{O}, 0.0021 ; \mathrm{NaMoO}_{4} .2 \mathrm{H}_{2} \mathrm{O}, 0.002$; $\mathrm{ZnSO}_{4} .7 \mathrm{H}_{2} \mathrm{O}, 0.0024 ; \mathrm{CuSO}_{4} .5 \mathrm{H}_{2} \mathrm{O}, 0.0016$ supplemented with $100 \mu \mathrm{g} / \mathrm{ml}$ tryptophan (Albrecht and Okon 1980).

\section{Cultivation of Plants}

Rice (Oryza sativa L.) was employed as an in planta model for monitoring endophytic colonization. The rice genotype used in this study was the variety Guarani, obtained from the Empresa Brasileira de Pesquisa Agropecuária (EMBRAPA, Goiânia, Brasil). Rice seeds were dehushed, surface sterilized and the sterilization efficiency was monitored by plating the processed seeds onto 
DYGS medium. Surface sterilized seeds were then aseptically transferred to water-based $1 \%$ agar plates for seed pre-germination. Following incubation for three days at $28^{\circ} \mathrm{C}$, in absence of light, the pre-germinated rice seed were aseptically transferred to glass tubes $(4 \mathrm{~cm}$ in diameter, $29 \mathrm{~cm}$ in height) containing $20 \mathrm{ml}$ of a nitrogen-free Hoagland's nutrient solution (Hoagland 1975).

\section{Bacteria Colonization Assay Using Rice as the in planta MODEL IN GNOTOBIOTIC AND HYDROPONIC CONDITIONS}

Plantlets were collected for detection and quantification B. kururiensis, "B. brasilensis" or E. coli population within internal plant tissues. Seven day-old plantlets were cut below the cotyledon. Surface sterilization of plant segments was optimized in order to successfully inactivate surface-colonizing bacteria, but not bacteria present within internal plant tissues (endophytic colonization). Sterilizing conditions tested for the plantlets were (i) $1 \%$ sodium hypochlorite for 5 min (Barac et al. 2004), or (ii) 5\% sodium hypochlorite for $1 \mathrm{~h}$ (Reinhold et al. 1986), followed by several washes with sterile water. Plant segments were subsequently immersed in $20 \mathrm{ml}$ of sterile wash solution ( $\mathrm{g} / \mathrm{liter}$ ): $\mathrm{KH}_{2} \mathrm{PO}_{4}, 4.23$; $\mathrm{K}_{2} \mathrm{HPO}_{4}, 5.41 ; \mathrm{NaCl}, 5.0 ; \mathrm{MgSO}_{4} .7 \mathrm{H}_{2} \mathrm{O}, 0.2 ; \mathrm{CaCl}_{2}$, $0.02 ; \mathrm{pH} 7.0$ ) in a $125 \mathrm{ml}$ Erlenmeyer, added with $3.0 \mathrm{~g}$ of glass beads and shaken at $200 \mathrm{rpm}$ for $30 \mathrm{~min}$, at $28^{\circ} \mathrm{C}$. The resulting supernatants were cultured on JMV agar, and any bacterial growth observed after threeday incubation at $28^{\circ} \mathrm{C}$ should be regarded as rhizoplane population that had resisted the surface sterilization. Surface-sterilized plants were mechanically macerated with $1 \mathrm{ml}$ sterile wash solution and ten-fold diluted in $0.8 \%$ saline. $100 \mu \mathrm{l}$ aliquots were plated onto $\mathrm{JMV}$ nutrient agar and incubated for 3 days at $28^{\circ} \mathrm{C}$. Recovery of viable bacteria from internal plant tissues provided evidence that they would endophytic colonization of rice plantlets. Surface sterilization with $1 \%$ sodium hypochlorite for $5 \mathrm{~min}$ (Barac et al. 2004) was regarded as optimum, allowing recovery of endophytic bacteria, but not from plant surfaces.

For rice seedlings inoculation bacteria obtained after $24 \mathrm{~h}$ of growth in liquid DYGS medium was harvested by centrifugation $\left(4,500 \times g, 15 \mathrm{~min}, 4^{\circ} \mathrm{C}\right)$ and the pellet resuspended in a nutrient solution containing (g/liter): $\mathrm{KH}_{2} \mathrm{PO}_{4}, 3.4 ; \mathrm{MgSO}_{4} .7 \mathrm{H}_{2} \mathrm{O}, 0.2 ; \mathrm{NaCl}, 0.1$; $\mathrm{CaCl}_{2}, 0.02 ; \mathrm{ZnSO}_{4} .7 \mathrm{H}_{2} \mathrm{O}, 0.0024 ; \mathrm{Na}_{2} \mathrm{MoO}_{4} .2 \mathrm{H}_{2} \mathrm{O}$; $\mathrm{H}_{3} \mathrm{BO}_{3}, 2.8 ; \quad \mathrm{CuSO}_{4} .5 \mathrm{H}_{2} \mathrm{O}, 0.0008 ; \mathrm{MnSO}_{4} \cdot \mathrm{H}_{2} \mathrm{O}$, $0.0235 ; \mathrm{KOH}, 4.5 ; \mathrm{FeCl}_{3} .6 \mathrm{H}_{2} \mathrm{O}, 0.0049$ and EDTA, $0.015 \mathrm{mg} ; \mathrm{pH} 7.0$ to a final optical density of 1.0 at $600 \mathrm{~nm}$ (approximately of $10^{9} \mathrm{cells} / \mathrm{ml}$ ). Plantlets invasion assays were carried out by inoculation with $100 \mu 1$ of the above bacterial suspension into the rhizosphere of each rich seedling in the glass tube. Non-inoculated control plantlets received only nutrient solution. After incubation for 7 days with a $12 \mathrm{~h}$ photoperiod at $28^{\circ} \mathrm{C}$, plantlets were collected and cut below the cotyledon to excise the roots as well as above it to recover the aerial parts of the plant (stems and leaves). The excised plant segments were subjected to surface sterilization as described above. Plant segments were then weighed and transferred to microfuge tubes containing $1 \mathrm{ml}$ of sterile nutrient solution and macerated with a pestle. From each of the obtained suspension, a series of 10-fold dilutions were prepared using sterile saline, and aliquots of $100 \mu 1$ were spread-plated onto DYGS medium and incubated for 4 days at $28^{\circ} \mathrm{C}$. The presence of viable bacteria was the initial indication of their ability to endophytically colonize rice plantlets. Bacterial quantification was expressed as $\mathrm{CFU} / \mathrm{g}$ of fresh weight plant tissue, and three replicates, from three independent colonizing assays were used to determine the average $\mathrm{CFU}$ values.

\section{B. kururiensis COLONIZATION ASSAY USING RICE AS THE in planta MODEL IN GREenHOUSE CONDITION}

Experiments using greenhouse condition were carried out using plantlets obtained under the same conditions described above. Inoculated and non-inoculated plantlets were maintained in $120 \mathrm{ml}$ test tubes for 15 days post-germination and then transplanted into soil-filled pots containing sterilized vermiculite and plantlets maintained under greenhouse conditions with temperature between $28^{\circ} \mathrm{C}$ and $30^{\circ} \mathrm{C}$, in the natural photoperiod from November to February. After transplantation, the soil surface was overlaid with sterile water up to $2 \mathrm{~cm}$ and irrigated when necessary. Recovery of endophyte bacteria from roots, stems and leaves of inoculated and noninoculated control plants was performed after 120 days postinoculation (dpi). Four replicate plants were re- 
moved from the pots, washed with tap water, disinfected with $1 \%$ sodium hypochlorite solution for $10 \mathrm{~min}$ and $70 \%$ ethanol for $1 \mathrm{~min}$, followed by a series of washing with sterile water. After surface disinfection, leaf, stem and root tissues were cut, weighed and ground in a mortar and pestle in $3 \mathrm{ml}$ of sterile saline. Homogenates were maintained at $28^{\circ} \mathrm{C}$ for $1 \mathrm{~h}$. Dilutions appropriated were plated onto JMV and DYGS media for 2-4 days at $28^{\circ} \mathrm{C}$ and $\mathrm{CFU}$ counting was used to confirm and quantify bacterial colonization within internal plant tissues. Observation of colony morphology and the sequencing of PCR-amplified 16S rDNA fragments were additional parameters used to identify the colonizing bacteria as being B. kururiensis.

\section{Evaluation of Plant Development in the PRESENCE OF B. kururiensis}

Effects of the B. kururiensis colonization on rice growth were assessed in greenhouse conditions. Inoculated and non-inoculated plants were incubated and maintained under the same conditions as described above, harvested 120 dpi after planting for measurements of height, wet weight, determination of the number of stems and flowering and amount of seed production. The same analyses described before were also performed to verify the bacterial establishment in a later stage of plant development. Fifteen replicates were used for each treatment, containing inoculated and non-inoculated control plants.

\section{B. kururiensis INFECTION ASSAY IN PRESENCE OR Absence of Nitrogen COMPOUNDS}

Influence of nitrogen sources on the endophytic establishment of B. kururiensis was evaluated in the conditions described above, for the gnotobiotic and hydroponic experimental conditions, with addition of a nitrogen compound. Rice plantlets were cultivated in $20 \mathrm{ml}$ mannitol-containing Hoagland's medium in absence or presence of $4 \mathrm{mM}$ or $8 \mathrm{mM}\left(\mathrm{NH}_{4}\right)_{2} \mathrm{SO}_{4}$. Plantlets were inoculated with $100 \mu \mathrm{l}$ of a bacterial suspension containing $10^{8} \mathrm{CFU} / \mathrm{ml}$ and maintained in a greenhouse for 7 days at $28^{\circ} \mathrm{C}$. Plantlets were surface-sterilized to estimate the endophytic population. Roots were excised, weighed, macerated in saline, and plated onto DYGS solid medium. Counting of $\mathrm{CFU} / \mathrm{g}$ in plantlet tissue after 7 dpi was used as an indicator of bacterial invasion capacity in the presence or absence of nitrogen source. Numbers of CFU/ml in the external rooting medium were also analyzed to determine bacterial viability in the presence of the nitrogen source.

\section{DNA MANIPULATION AND PCR AMPLIFICATION}

DNA template used for PCR amplification of the $16 \mathrm{~S}$ rDNA was obtained either directly, from extracts of roots and shoots (from 7-dpi plantlets) or indirectly by genomic DNA extraction from bacteria isolated from 120-dpi plants. Axenically grown rice surfaces were disinfected with $70 \%$ ethanol and plantlet tissues were ground with a mortar and pestle in $1 \mathrm{ml}$ of extraction buffer consisting of $0.01 \mathrm{M}$ phosphate-buffer $\mathrm{pH} 7.2$; $0.14 \mathrm{M} \mathrm{NaCl} ; 0.1 \%$ Tween $20 ; 0.5 \%$ polyvinyl-polypyrrolidone powder (PVPP, Sigma, St Louis, MO, USA); and $0.5 \%$ polyvinyl-pyrrolidone (PVP, Sigma, St Louis, MO, USA). The insoluble PVPP was removed by low speed centrifugation at $110 \times g$ for $10 \mathrm{~min}$ and a $2 \mu 1$ aliquot of supernatant was directly subjected to PCR. In the case of the greenhouse experiment (120 dpi) the DNA template was obtained from greenish isolated colonies grown on DYGS plates recovered from plant tissue and subsequently grown in liquid DYGS medium for $48 \mathrm{~h}$ at $28^{\circ} \mathrm{C}$. Genomic DNA was then extracted from bacterial culture. A $16 \mathrm{~S}$ rDNA fragment was amplified with $5 \mu 1$ of $20 \mu \mathrm{M}$ solutions of each universal eubacterial primers, 907R (5'CCGTCAATTCMTTTGAGTTT3') and 27F (5'AGAGTTTGATCCTGGCTCAG3'). Universal primers were designed from conserved bacterial sequences at the 5' and 3' ends of the $16 \mathrm{~S}$ rRNA gene (Marin et al. 2003). Amplification was carried out in a $25 \mu 1$ reaction, containing either $50 \mathrm{ng}$ of bacterial genomic DNA or 1$3 \mu \mathrm{l}$ of plant extract as template, $200 \mu \mathrm{M}$ of each dNTP, $3.75 \mathrm{mM} \mathrm{MgCl}_{2}$ and $1 \mathrm{U}$ of Taq DNA polymerase (Invitrogen). $\mathrm{PCR}$ cycles consisted of denaturation at $95^{\circ} \mathrm{C}$ for $10 \mathrm{~min}, 40$ cycles of denaturation at $95^{\circ} \mathrm{C}$ for $45 \mathrm{~s}$, annealing at $54^{\circ} \mathrm{C}$ for $1 \mathrm{~min}$ and primer extension at $72^{\circ} \mathrm{C}$ for $1 \mathrm{~min}$; followed by a final extension at $72^{\circ} \mathrm{C}$ for 10 min. Amplified products were resolved in $1 \%$ agarose gel in TAE buffer and visualized with SYBR Green I dye (Sigma, St Louis, MO, USA). A standard DNA marker (Lambda/PstI) (Gibco BRL) was used. Amplified 16S rDNA fragment was purified directly using GFX PCR DNA and Gel Band Purification kit (Amersham 
Pharmacia Biotech), as recommended by the manufacturer. Nucleotide sequence of the amplified 16S rDNA fragment was determined with primers $907 \mathrm{R}$ and $27 \mathrm{~F}$, in a Perkin Elmer ABI/Prism 377 automated DNA sequencer according to manufacturer's instructions. DNA sequences were analyzed for identity with the BLAST program (http://www.ncbi.nlm.nih.gov/BLAST).

\section{SCANNING EleCtron Microscopy (SEM)}

Plant tissues collected 7 dpi were washed twice with sterile water, fixed with $2.5 \%(\mathrm{v} / \mathrm{v})$ glutaraldehyde and $4 \%(\mathrm{v} / \mathrm{v})$ paraformaldehyde in $0.1 \mathrm{M}$ sodium cacodylate buffer, $\mathrm{pH} 7.2-7.4$, for $2 \mathrm{~h}$ at $28^{\circ} \mathrm{C}$. Fixed tissues were washed three times with phosphate buffered saline (PBS, $\mathrm{pH}$ 7.2) and cut to separate roots and aerial parts. Plant segments were post-fixed in $1 \%(\mathrm{w} / \mathrm{v})$ osmium tetroxide in PBS, for $2 \mathrm{~h}$ at $4^{\circ} \mathrm{C}$, dehydrated in a $50-100 \%$ (v/v) gradient ethanol series, and dried by the $\mathrm{CO}_{2}$ critical point method in a Balzers apparatus, model CDP-20. Samples were subsequently mounted on aluminum stubs with double coated carbon conductive tape (Pelco Int.) and sputtered with gold in a Balzers apparatus, model FL-964. Observations and micrographies were made in a Jeol JSM-5310 scanning electron microscope.

\section{Transmission ELECTRON Microscopy (TEM)}

Intact roots of plants 7 dpi were washed, fixed, sectioned, post-fixed, and dehydrated as described above for SEM. The sections obtained from the upper pillow region of the roots were embedded in Spurr ${ }^{\circledR}$ (Polysciences, Inc. Warrington, PA, USA). Then, ultrathin sections $(50-70 \mathrm{~nm}$ thick) stained in uranyl acetate $5 \%(\mathrm{w} / \mathrm{v})$ and in lead citrate were observed and photographed in a transmission electron microscope (FEI - Morgagni).

\section{Detection of Bacterial Auxin Production by B. kururiensis USING AUXIN INDUCIBLE REPORTER DR5-GUS}

O. sativa (L.) Japonica cultivar Taichung 65, transgenic to the auxin-inducible reporter DR5-GUS, has been described previously (Scarpella et al. 2003) and was kindly provided by Dr. Annemarie Meijer (Institute of Biology, Leiden University, The Netherlands). Seeds from, at least, the third generation of the progeny, homozygous for the transgene, were used. Initially, seeds had their surface sterilized with $0.2 \% \mathrm{HgCl}_{2}$ for $5 \mathrm{~min}$ and germinated in a $12 \mathrm{~h} \mathrm{light}$ at $28^{\circ} \mathrm{C}$ for seven days on Murashige and Skoog medium (MS medium) (Murashige and Skoog 1962) supplemented with (g/liter): 10.0 sucrose and 7.0 agar. An aliquot of B. kururiensis containing $10^{8} \mathrm{CFU} / \mathrm{ml}$ of a $48 \mathrm{~h}$ culture in DYGS medium $(500 \mu \mathrm{l})$ was used to inoculate seven-day seedlings of transgenic plantlets. Control DR5-GUS plantlets were inoculated with sterile water instead of bacterial suspension. DR5GUS expression was assessed by histochemical staining for GUS, $12 \mathrm{~h}$ postinoculation.

\section{HistochemicAl STAINING FOR GUS ACTIVITY}

The basal part of inoculated rice plantlets, mainly the radicular system, was immersed in a solution consisting of $1 \mathrm{mg} / \mathrm{ml}$ 5-bromo-4-chloro-3-indolyl $\beta$-D-glucuronide (X-Gluc, Sigma) solution in $100 \mathrm{mM}$ sodium phosphate buffer $\mathrm{pH} 7.2 ; 0.1 \%$ Triton X-100; 10 mM EDTA; $5 \mathrm{mM} \mathrm{K}_{4} \mathrm{Fe}(\mathrm{CN})_{6} ; 5 \mathrm{mM} \mathrm{K} 3 \mathrm{Fe}(\mathrm{CN})_{6}$ at $37^{\circ} \mathrm{C}$ in darkness for $30 \mathrm{~min}$ and subsequently cleared in $70 \%$ ethanol, before visualization. GUS expression was examined with an optical microscope (BX50; Olympus) and images recorded with a digital camera (CoolSnap-Pro; Olympus). The image was digitally controlled and analyzed using the Image-pro-Plus, version 4.1, software package.

\section{IAA BiologicAl Assay}

O. sativa (L.) seeds were surface sterilized as described above. The plantlets were grown in hydroponic medium supplemented with $B$. kururiensis $\left(10^{8}\right.$ cells) cultured in MAZ culture medium or filter-sterilized B. kururiensis culture supernatant (corresponding to $5 \mu \mathrm{g}$ of indole compounds estimated by Salkowski reagent (Elmann 1977)). MAZ culture medium $(500 \mu \mathrm{l})$ or addition of $50 \mu \mathrm{M}$ IAA (Sigma) was used as a negative or positive controls, respectively. Root hair production was assessed after $24 \mathrm{~h}$ and viewed under optical microscopy.

\section{ANALYSIS OF BACTERIAL IAA}

Analysis of IAA was performed by colorimetric assay in cell-free culture supernatant with Salkowski reagent (Elmann 1977) or by gas liquid chromatography-mass spectrometry (GC-MS). The bacterial culture supernatant was adjusted to $\mathrm{pH} 2.5$ with $3 \mathrm{M} \mathrm{HCl}$. IAA ex- 
traction was performed in three stages with the addition of equal volume of ethyl acetate (Crozier et al. 1988). The extracts were dried under vacuum and the resulting concentrates were dissolved in $2 \mathrm{ml}$ of methanol, applied to a reverse-phase LC-18 SPE column (Supelco) (Tomita et al. 1987) and eluted with a solution containing $40 \%$ isopropanol (v/v) and 5\% acetic acid (v/v). Trimethylsilylated derivative (TMS) samples and standard IAA were prepared by dissolving in $15 \mu \mathrm{l}$ acetonitrile and $15 \mu \mathrm{l}$ of bis-(trimethysily)trifluoroacetamide, heated at $70^{\circ} \mathrm{C}$ for $10 \mathrm{~min}$. GC-MS analyses were performed in a Shimadzu GC 17 A gas chromatograph, equipped with a DB-1 capillary column, interfaced with a GCMS-QP5050 quadruple mass spectrometer (Shimadzu). Electron ionization (EI) was performed using an ionization potential of $70 \mathrm{eV}$ and an ionization current of $0.2 \mathrm{~mA}$ (Mattos et al. 2005). The temperature program for the analysis TMS derivatives ranged from $155^{\circ} \mathrm{C}$ to $200^{\circ} \mathrm{C}$ at $10^{\circ} \mathrm{C} \mathrm{min}^{-1}$.

\section{Statistical Methods}

Statistical analyses were performed with Excel (Microsoft, version 5.0) software package; and statistical differences were analyzed for significance with the two-tailed Student's $t$-test. A $P$-value $<0.01$ was considered significant.

\section{RESULTS}

\section{B. kururiensis ESTABLISHES TYPICAL ENDOPHYTIC Association With Rice}

Efficient establishment of endophytic colonization of rice plants by $B$. kururiensis was demonstrated with a gnotobiotic system, using axenic rice plantlets. B. kururiensis and "B. brasilensis" (data not shown) were successfully isolated from both roots and aerial parts of the host plants and a markedly high recovery were recorded from the mixture of leaves and stems of 7 dpi plantlets. The average number of $B$. kururiensis endophytically colonizing roots and shoots of rice was respectively $8.5 \times 10^{9}$ and $2.95 \times 10^{6} \mathrm{CFU} / \mathrm{g}$ of fresh weight plantlet tissue. Colonization extent was considerably higher in roots, compared to stems and leaves. No bacteria could be isolated from non-inoculated plants or plants inoculated with $E$. coli $\mathrm{E}$ 2348/69.

Assessment at $120 \mathrm{dpi}$ reflected the number of $\mathrm{CFU} / \mathrm{g}$ of wet weight of roots or stems or leaves. Tempo- ral changes in bacterial densities according to the plant age were observed. In this case, bacterial counting was in the order of $8.0 \times 10^{2}$ and $7.5 \times 10^{2} \mathrm{CFU} / \mathrm{g}$ of fresh weight in roots and aerial parts (stems and leaves), respectively.

\section{B. kururiensis INFECTION ROUTE INVOLVES VASCULAR Colonization}

Interaction between rice roots from $7 \mathrm{dpi}$ plantlets and $B$. kururiensis obtained under gnotobiotic conditions was observed by SEM. Rod-shaped bacteria were observed, mostly in pairs or in small tridimensional microcolonies covering the root surface (Fig. 1C-E). A major presence of bacteria was observed mainly in the root hair zone (Fig. 1C) where bacteria were apparently adhered to the root epidermal cells. Bacteria were particularly accumulated in the basal portion of the root hair, forming microaggregates on disrupted areas of the epidermal surface (Fig. 1D-E). Such damage of the epidermal surface on heavily colonized areas suggests an active invasion mechanism, probably associated to a high density of bacterial population as compared to the non-infected control plant (Fig. 1A-B). Figure 2A shows consecutive stages of $B$. kururiensis endophytic colonization, characterizing the infection route in rice roots. Following colonization and disruption of epidermis, bacteria appear invading the apoplast (Fig. 2B).

Further analysis of the interaction using TEM showed that B. kururiensis entered the primary roots after $7 \mathrm{dpi}$. The invasion process followed a pattern with fewer bacteria observed entering the roots and the Burkholderia mainly localized within intercellular spaces of the parenchyma cells (Fig. 3A-F). At this stage, B. kururiensis was observed entering the inner cortex along the vascular cylinder where it was visualized by SEM as strings and large microcolonies inside xylem vessels (Fig. 2D-E). No bacteria were observed by SEM on the surface (Fig. 1A-B) or within the tissues (Fig. 2G) of non-infected control plants.

In order to verify $B$. kururiensis capacity as a plant-growth-promoting bacterium, traits like length, weight, flowering and seed production were measured in inoculated rice plants and compared with non-inoculated controls in greenhouse experiments. Records of plant growth were determined at different times after inoculation, with whole and fragmented plant samples. 

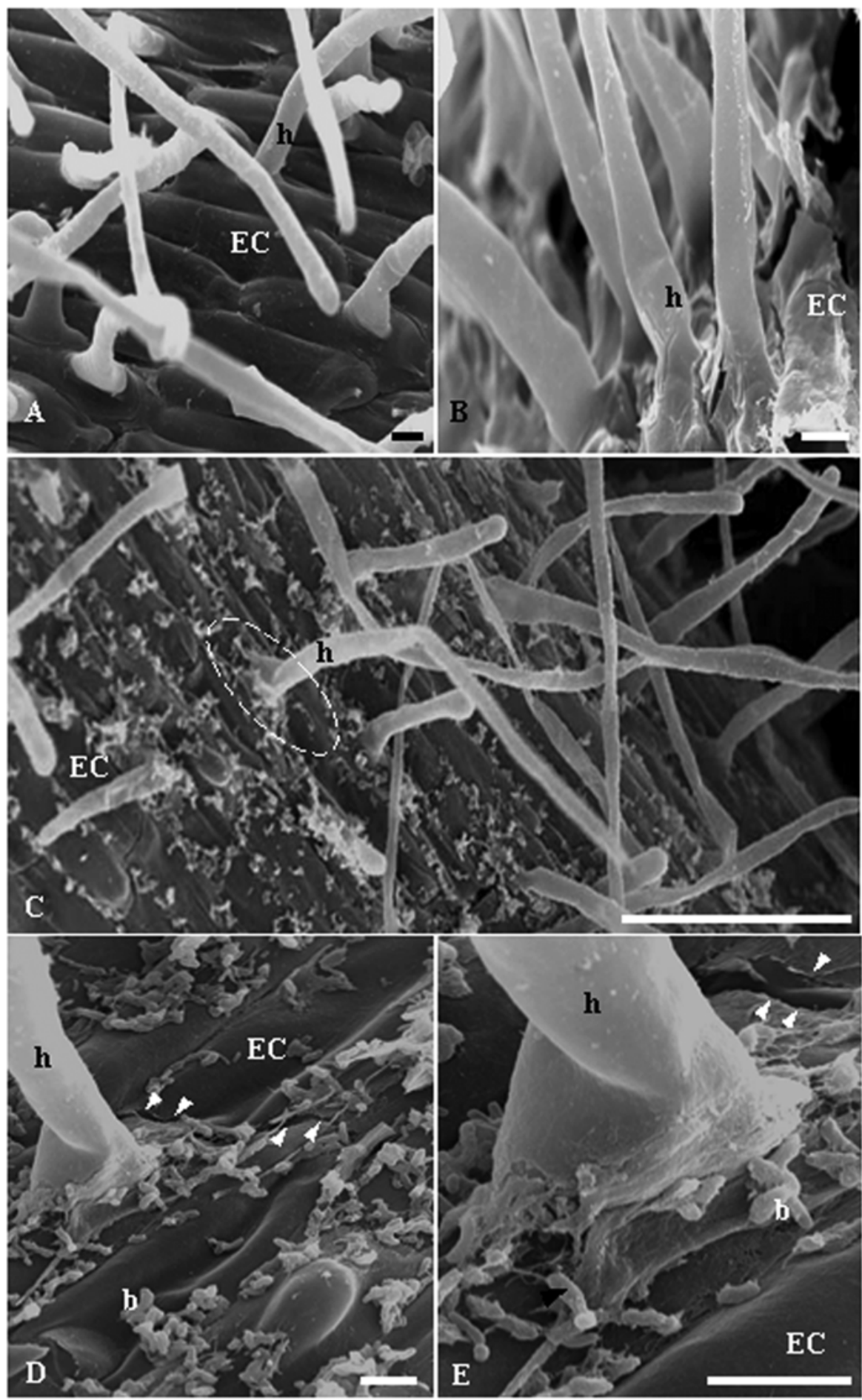

Fig. 1 - SEM of rice root colonization (root hair zones) by B. kururiensis at $7 \mathrm{dpi}$. SEM from roots of uninfected control plantlet under gnotobiotic conditions (A, B). Note that no bacteria are present on the root hair $(\mathbf{A})$ or their bases $(\mathbf{B})$. In $(\mathbf{C})$ is the general view of the root surface covered with bacteria. The pointed ellipse shows area around the hair base where invasion may occur. (D) Zoomed view of the area inside the ellipse showing the destruction bacterial clusters frequently present on the hair base, and their adhesion onto the rhizoplane, possibly representing a focused attack to the root epidermis (arrowheads), best visualized under high magnification $(\mathbf{E})$. EC, epidermal cells; $\mathbf{h}$, root hair; $\mathbf{b}$, bacteria. Bar $=1 \mu \mathrm{m}$. 


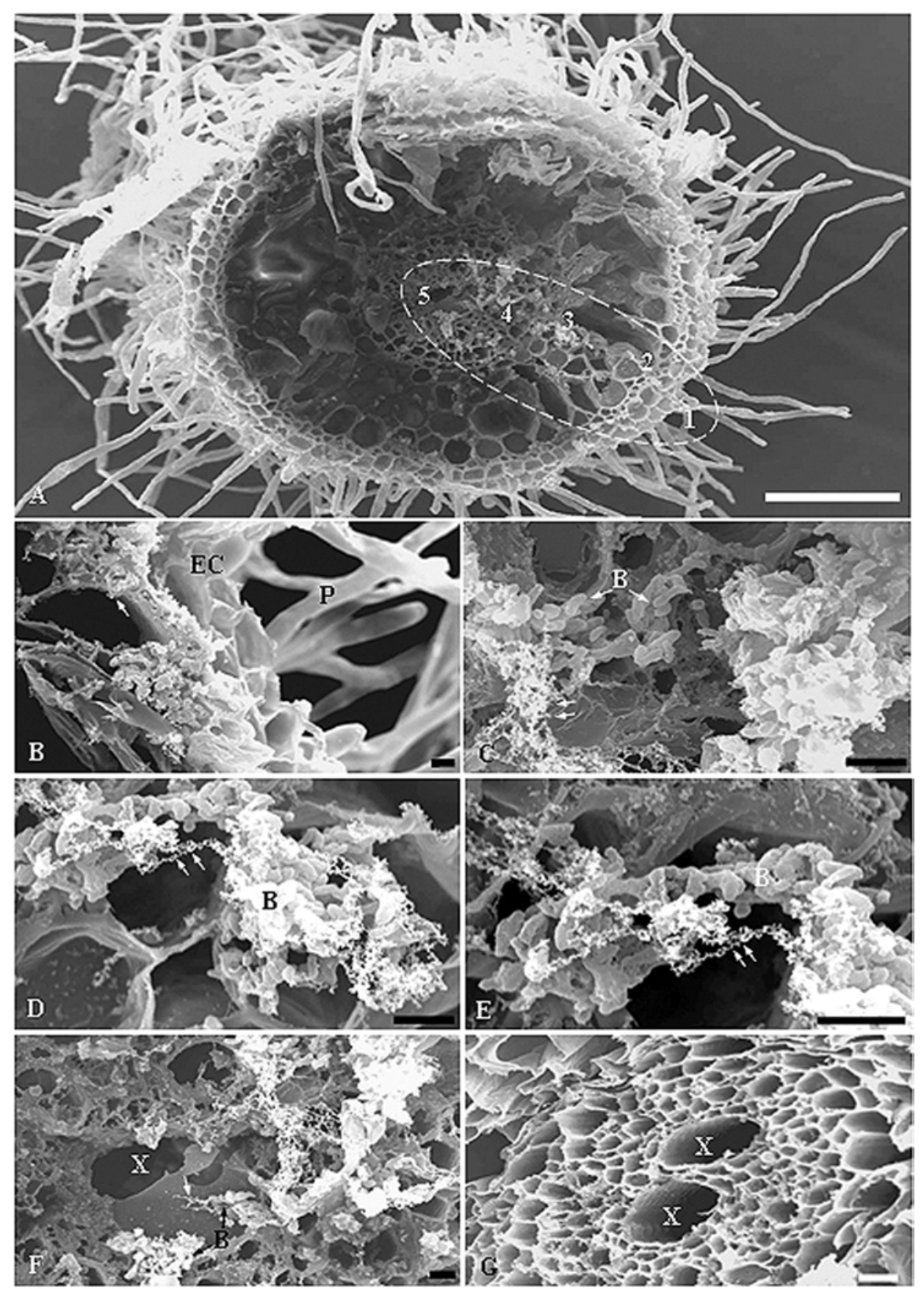

Fig. 2 - SEM showing the infection route by B. kururiensis. (A) General view of a transversal section of an infected root where five zones (1-5) are distinguished characterizing the pathway taken by bacteria from the epidermal surface towards the xylem vessels. (B) Detailed view of zone 1: bacteria invade the inner tissues through the hair base, crossing epidermal cells and the apoplast, eventually migrating to the cortex cells. (C, D) View of zones $\mathbf{2}$ and $\mathbf{3}$, respectively, evidencing clusters of bacteria arranged in strings within the inner cortex, along the vascular cylinder. Filamentous material (white arrows) is observed on root cells, nearby adhered bacterial clusters. (E) Vascular cylinder (zone 4) showing bacteria still arranged in strings. Note that during the root invasion process, bacteria are apparently translocated through intercellular spaces. (F) Center of a vascular cylinder (zone 5) evidencing the arrival of bacterial strings inside the xylem (X) vessels, best visualized in (G). Transversal section of an uninfected control root, showing xylem vessels free from bacteria. $\mathbf{E C}$, epidermal cells; $\mathbf{P}$, root hair; $\mathbf{X}$, xylem vessels, $\mathbf{B}$, bacteria. Bar $=1 \mu \mathrm{m}$. 


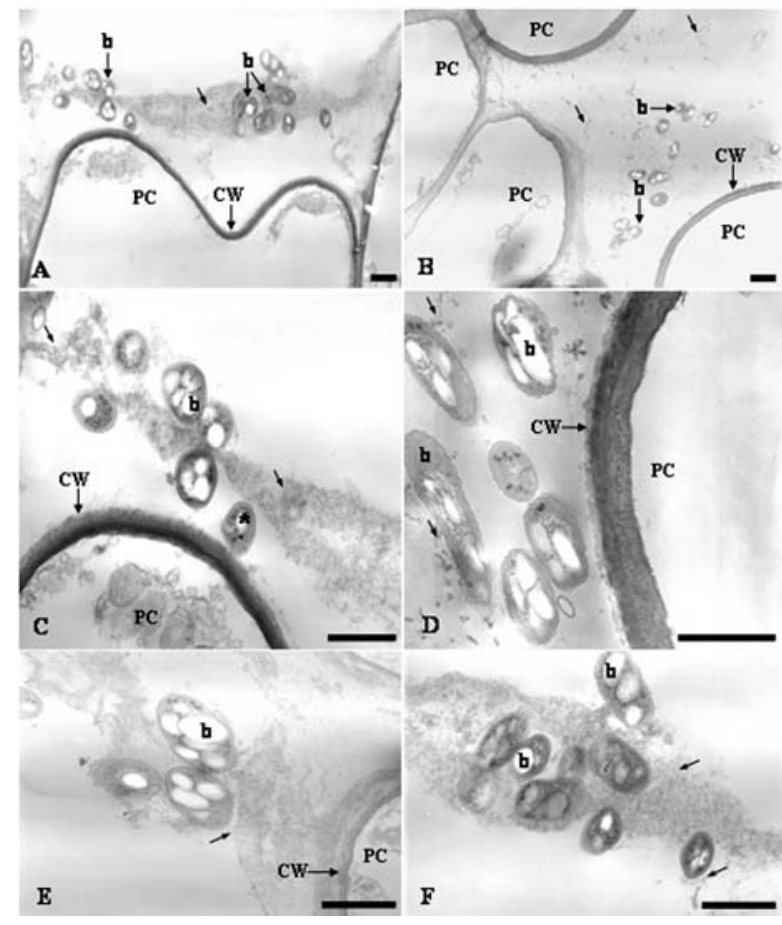

Fig. 3 - TEM of the cortex region of the root 7 days incubated with $B$. kururiensis. In (A) and (B) are shown a general view of the bacteria invasion. Note that bacteria can be observed close to the parenchyma cells (PC) surface (A) or in the intercellular space among these cells (B). In (C) and (D) these bacteria are seen close $\left(^{*}\right)$ to the parenchyma cell wall $(\mathbf{C W})$ or associated to a fibrilar material (thin arrows) commonly presented in the intercellular space, that seems to be involved in the formation of bacteria clusters during their interaction with the host plant $(\mathbf{E}$ and $\mathbf{F})$. Bar $=1 \mu \mathrm{m}$.

Significant increases in relative fresh weight of whole and isolated parts of the plants, as of flowering and seed production were observed in the analyses of mature plants (Fig. 4A-F). A noteworthy data was observed in the weight and thickness of the roots from inoculated plants, when compared with controls (Fig. 4B). The most remarkable difference was observed in the relative fresh weight of roots and aerial parts (Fig. 4C-D). Other scored yield-increasing traits were flowering and seed production per pot in inoculated plants as compared to control experiments (Fig. 4E-F).

\section{B. kururiensis DETECTION BY 16S RDNA PCR AMPLICATION AND SEQUENCING}

PCR amplification of a B. kururiensis chromosomal sequence was performed with universal bacterial $16 \mathrm{~S}$
rDNA primers, which yielded a product with around $900 \mathrm{bp}$. The template DNA was prepared either directly from the roots and shoots of the infected plantlets (7 dpi) or from genomic DNA purified from bacterial cells isolated of mature plants (120 dpi) (data not shown). PCR products were obtained with universal eubacterial primers, which required additional approach for specificity, as DNA sequencing. Both DNA strands were sequenced and BLAST search was performed, confirming $100 \%$ identity to the corresponding B. kururiensis $16 \mathrm{~S}$ rDNA (GenBank accession number AY586520).

When plant tissues were ground without treatment with PVP and PVPP, amplification was not obtained, suggesting the presence of inhibitory substances in plant extract. PCR efficiency in plant samples was tested using extracts to which B. kururiensis had been added. Samples taken from mature plants interfered with the PCR (Maes et al. 1996), blocking or decreasing the PCR amplification. Furthermore, the PCR efficiency depended upon the physiological condition of the assayed plant tissue as plant age, since PCR amplification of eubacterial $16 \mathrm{~S}$ rDNA directly from total tissues DNA was successful from plantlets up to 7 dpi but negative from mature plant tissues (data not shown). Negative results were probably due to the low number of bacteria inside those plants.

\section{ESTABLISHMENT OF B. kururiensis ENDOPHYTIC COLONIZATION IS IMPAIRED BY NITROGEN FERTILISATION IN A DOSE-DEPENDENT MANNER}

The influence of nitrogen fertilization in the experiments conducted with B. kururiensis was performed with axenic plantlets cultured on Hoagland's solution supplemented with $4 \mathrm{mM}$ or $8 \mathrm{mM}\left(\mathrm{NH}_{4}\right)_{2} \mathrm{SO}_{4}$. Plantlets cultivated for 7 days in the presence of $\left(\mathrm{NH}_{4}\right)_{2} \mathrm{SO}_{4}$ showed a significant decrease in bacterial invasion levels as compared to the corresponding non-inoculated controls. Furthermore, an inverse correlation between the numbers of $B$. kururiensis colonizing roots and the concentration of nitrogen supply was evident. The CFU counting from fresh root tissues was higher when lower nitrogen concentration of $4 \mathrm{mM}\left(\mathrm{NH}_{4}\right)_{2} \mathrm{SO}_{4}\left(9.9 \times 10^{7}\right.$ cells) was supplied, compared to the CFU counting in presence of $8 \mathrm{mM}\left(\mathrm{NH}_{4}\right)_{2} \mathrm{SO}_{4}\left(4.34 \times 10^{5}\right.$ cells). Interestingly, 7 days after $B$. kururiensis inoculation in gno- 

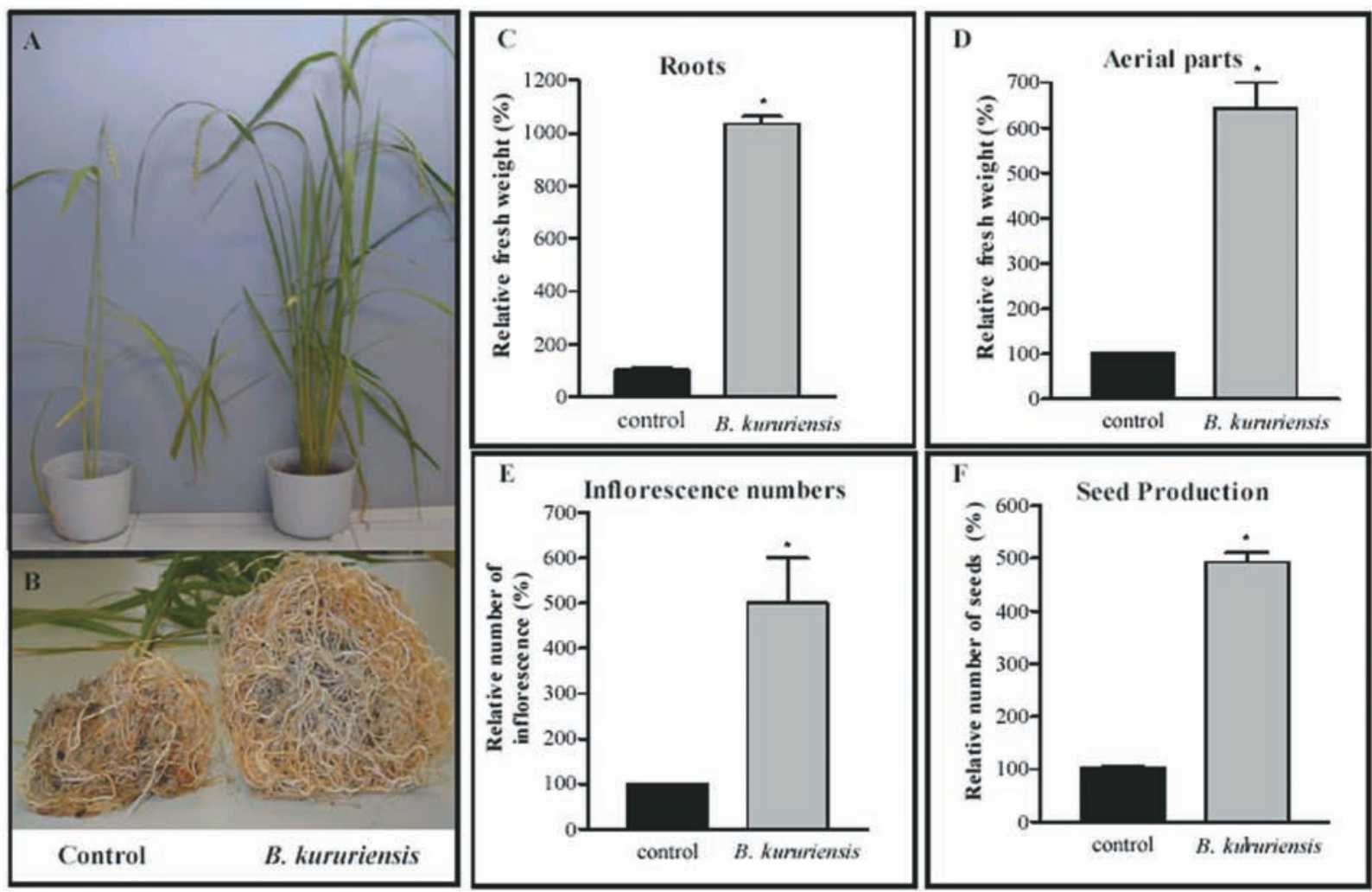

Fig. 4 - Enhanced rice development promoted by B. kururiensis association. Picture shows a comparative view of inoculated and non-inoculated plants at 120 dpi. (A) Aerial parts showing extensive differentiation. (B) Root system showing significant difference in weight and thickness. (C) Percentages of relative fresh weight of root systems and (D) aerial parts. (E) Percentage of relative flowering numbers, and seed production (F). Bars represent means, and error bars indicate standard deviations.

tobiotically cultured plantlets the number of viable bacteria in the external rooting medium range in $10^{11} \mathrm{CFU}$, regardless the amount of nitrogen supply.

\section{INDUCTION OF INDOLE-3-ACETIC ACID (IAA) REPORTER ACTIVITY BY B. kururiensis}

Transgenic seven-day-old rice plantlets, containing the auxin-inducible reporter DR5-GUS, were inoculated with B. kururiensis to assess its ability to induce the production of IAA. $24 \mathrm{~h}$ after inoculation, clear differences were observed in the distribution of GUS activity within the plant as compared to non-inoculated plantlets. Infected plantlets showed blue cells in the root cortex and vascular cylinder indicating that the observed staining was due to activity of the GUS enzyme, suggesting that DR5-GUS expression was up-regulated in the presence of B. kururiensis due to bacterial auxin production and secretion within plant tissues. Infected roots showed intensive blue colour, which included root hairs, apical region of the roots and meristem tissues (Fig. 5B). In several places, a clear, more intense staining was observed in the vascular cylinder due to a higher reporter activity. Colonization by B. kururiensis induced, in all inoculated plants, a large increase in root hair number and length (Fig. 5B). The non-inoculated plantlets exhibit a typical blue staining indicative for GUS basal activity in the root tip, which was higher than in the rest of the root, probably due a higher amount of endogenous auxin at this meristematic tissue (Fig. 5A). Aerial parts were not analyzed for GUS activity.

\section{ANALYSIS OF IAA}

Production of bacterial indol compounds was investigated by analyzing cell-free culture supernatant with Salkowski reagent (Elmann 1977) after $72 \mathrm{~h}$ incubation. The supernatant contained an average of $5 \mu \mathrm{g}$ of indol 


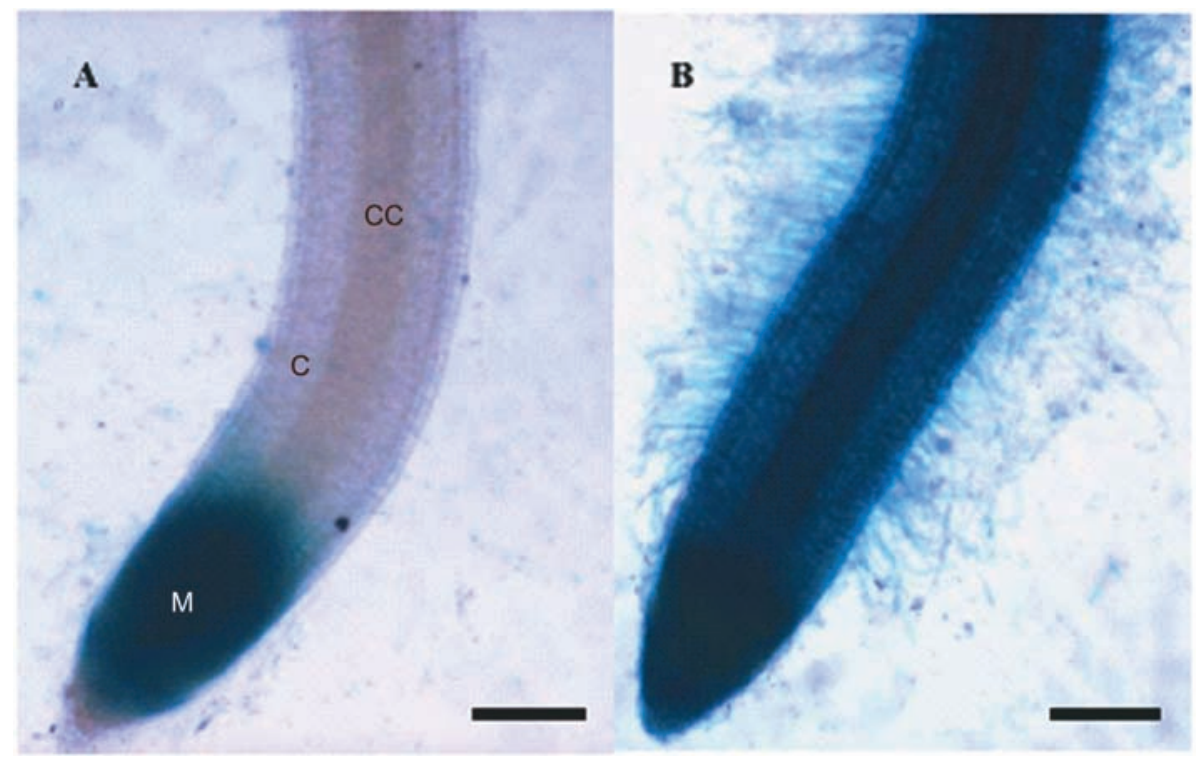

Fig. 5 - Bright field microscopy of the GUS expression pattern in the root of transgenic seven-dayold rice plantlets. (A) DR5-GUS activity in control plantlets was detected only in the meristematic tissue, M. (B) Root system showing extensive blue stained due the DR5-GUS activity in response to B. kururiensis. Radicular cortex, C; Central cylinder, CC; Bar $=100 \mu \mathrm{m}$.

compounds/ml of culture. Based on GC-MS analysis the acidic indole fraction of bacterial culture supernatant showed a retention profile and mass fragmentation pattern identical to that of IAA standard. Monitored ions were $\mathrm{m} / \mathrm{z} 202$ for the base peak (quinolinium ion) and $\mathrm{m} / \mathrm{z} 319$ for the molecular ion (IAA with a trimethylsilyl on the carboxyl and on the indolylic nitrogen) (Allen et al. 1979) (data not shown).

\section{EFFECT OF IAA PRODUCED BY B. kururiensis ON THE DEVELOPMENT OF ROOTS}

The effect of supernatant of $B$. kururiensis culture on the rice roots was verified by microscopy. The presence of a higher number of lateral roots and more abundant root hairs were observed in response to the $B$. kururiensis supernatant when compared with either $B$. kururiensis or standard IAA-inoculated roots (Fig. 6). The present observation on bioassays in rice plantlets clearly demonstrates that $B$. kururiensis culture supernatant displays a typical auxin activity, such as lateral root formation. This finding is strongly supported by the GC-MS analysis profile mentioned above, which demonstrates the presence of a typical IAA molecule (data not shown).

\section{DISCUSSION}

The Gramineae rice (Oryza sativa L.) was chosen as a plant model in this study with the aim of investigating B. kururiensis ability to colonize plant tissues. This bacterium is a TCE-degrading bacterium isolated from an aquifer sample collected at a TCE-polluted site in Japan (Zhang et al. 2000) and has the ability to fix nitrogen (Estrada-de los Santos et al. 2001). The main driving force to determine this putative plant-bacteria association was the phylogenetic closeness between $B$. kururiensis and "B. brasilensis" (Baldani and Baldani 2005, Estradade los Santos et al. 2001, Marin et al. 2003), an endophytic diazotrophic bacterium isolated from rice in Brazil (Baldani et al. 1997) which have a $100 \%$ similarity with the $n i f H$ gene sequence with $B$. kururiensis (Marin et al. 2003). In fact, " $B$. brasilensis" has very recently been reclassified as $B$. kururiensis (CaballeroMellado et al. 2007). These data emphasizes the wide geographic and environmental distribution of the species $B$. kururiensis.

In the present study, we demonstrate that B. kururiensis can invade rice roots, spreading rapidly and systematically through the plant tissues and finally leading 


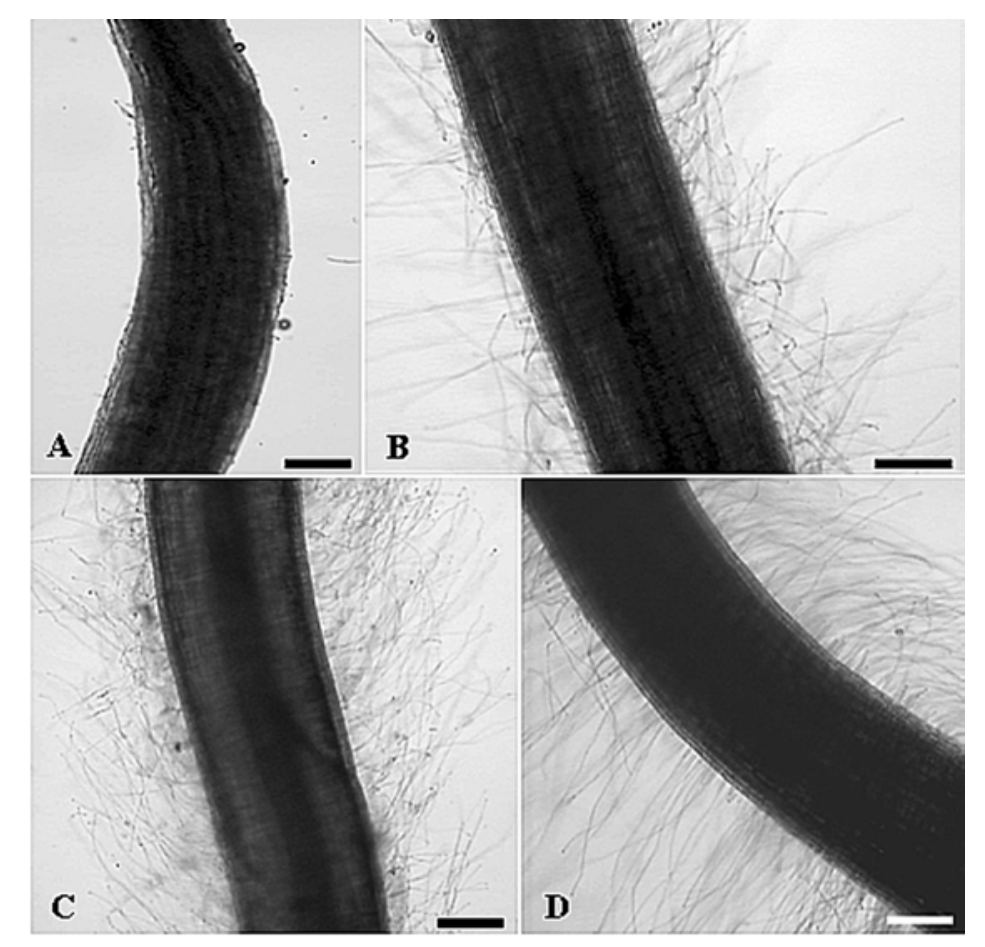

Fig. 6 - Effect of IAA produced by B. kururiensis on root hairs of O. sativa grown in vitro. Treated plants were incubated for $24 \mathrm{~h}$ in hydroponic media supplemented with (A) medium non-inoculated $(500 \mu 1)$; (B) $50 \mu \mathrm{M}$ IAA standard; (C) $10^{8}$ B. kururiensis cells; (D) filter-sterilized culture supernatants of B. kururiensis. Bar $=200 \mu \mathrm{m}$.

to a remarkably enhanced plant growth and seed production. Since analysis of auxin/IAA was unequivocally identified in culture supernadant of $B$. kururiensis we proposed that IAA signaling is essential for guiding auxin-mediated those plant responses. Recently, the production of IAA in B. vietnamiensis has been described (Govindarajan et al. 2008). Herein, we demonstrate $B$. kururiensis ability to endophytically colonize rice plants, from 7 days and to remain for, at least, 120 dpi within mature and fertile rice plants. At 7 dpi all rice plantlets studied were found endophytically colonized by B. kururiensis with approximately $10^{9} \mathrm{CFU} / \mathrm{g}$ of root fresh weight. Although this bacterium had persisted inside rice tissues farther than the initial point of colonization, the number of cells among the tested 120 dpi plants was variable. Opposite pictures are observed in pathogenic plant infections, where the presence of characteristic symptoms is directly correlated with very high numbers of bacteria within the vascular bundles in later stages of infec- tion (Purcell and Hopkins 1996, Sabaratnam and Beattie 2003). After 120 dpi the rice plants inoculated with $B$. kururiensis did not show any pathologic symptoms.

Distribution of nitrogen-fixing microorganisms in the environment is typically influenced by several factors, such as period of the year, physiological state of the plant (i.e. age) and nitrogen fertilization (FuentesRamírez et al. 1993). Remarkably, sensitivity of many diazotrophic bacteria to nitrogen fertilizers could affect their endophytic ability (Fuentes-Ramírez et al. 1993, Munõz and Caballero-Mellado 2003, Muthukumarasamy et al. 2002, Ramey et al. 2004, Tan et al. 2003). In agreement, we have demonstrated that nitrogen fertilization was a limiting factor for the recovery of $B$. kururiensis from internal plant tissues, as evidenced by selective growth patterns in different concentrations of $\left(\mathrm{NH}_{4}\right)_{2} \mathrm{SO}_{4}$. This effect does not seem to be a direct negative effect of the fertilizer on the bacteria, since nitrogen supply is not a limiting factor on the B. kururiensis 
growth pattern, in pure bacterial cultures. However, our data provide evidences that nitrogen can limit the bacterial invasion process, depending on its concentration.

In addition, our results distinguish consecutive stages of B. kururiensis invasion in rice roots, characterizing a possible infection route. The initial step consists of the attachment of bacteria onto epidermal cells of the root surface, where root hair zone represent one of the major sites of primary colonization, mainly on the basal region of emerging hairs. At this stage, filamentous structures were observed in the microscopic analysis, apparently promoting bacteria-to-bacteria and bacteria-to-plant surface cross-linking. Similar observations have been described in other endophytic interactions, resembling bacterial polysaccharide-like structures that may point to crucial stages of ligand-receptor apparatuses with significant potential to modulate the plant-bacteria interactions (Bacilio-Jiménez et al. 2001, James et al. 1994, Ramey et al. 2004, Roncato-Maccari et al. 2003). However, the nature and origin of these fibrils present on inoculated rice are unknown yet. Next, a second stage was characterized by bacterial proliferation through basal hair tissues, where superficial damages were readily detected suggesting an active process, probably mediated by cell wall-degrading enzymes, allowing cortical infection by apoplastic dispersion of bacteria as previously described for H. seropedicae and G. diazotrophicus (Dong et al. 1997, Roncato-Maccari et al. 2003). Although the superficial tissue damage resembles an aggressive mode of invasion, a similar picture has been already observed during the interaction of rice with beneficial bacteria like H. seropedicae (James et al. 1994). A third stage was consistent with the intercellular invasion of the internal tissues and subsequent entrance into the root vascular system, where bacteria could possibly be translocated to the lower stem in the xylem. The main localization of $B$. kururiensis in xylem vessels suggests that systematic spreading into shoots may be mediated through the transport vessels. The systematic spreading of $B$. kururiensis into young rice roots was supported by independent lines of evidence (microscopy, 16S rDNA PCR amplification and CFU counting) prepared from rice tissues. This study is clearly showing that $B$. kururiensis colonization of rice seedlings occurs in a similar fashion to that described for several nitrogen- fixing grass endophytes, such as Azoarcus sp., H. seropedicae, G. diazotrophicus (Hurek et al. 1994, James et al. 1997).

Several authors showed that endophytic diazotrophic bacteria as $G$. diazotrophicus (Sevilla et al. 2001), H. seropediceae (Baldani et al. 2000, Baldani and Baldani 2005, James and Olivares 1998), Azospirillum brasilense (Bacillo-Jiménez et al. 2001), B. vietnamiensis (Trân Van et al. 2000) and "B. brasilensis" (Baldani et al. 2000, Baldani and Baldani 2005, Oliveira et al. 2002) have the ability to increase the total dry matter of host plants to which they associate, suggesting an effect of these bacteria as plant-growth-promoting agents. We propose that $B$. kururiensis can be included in the associative category mentioned above, because it positively acts as a plant growth-promoting agent, also resulting in increased seed yields. The most remarkable plant benefit was observed as the increase in root biomass of plants at 30 to 120 dpi. However, our results demonstrate that, at least for the analyzed rice species, the community of root-colonizing diazotrophs is not stable, as the environment (e.g. availability of nitrogen compounds) and especially plant physiology parameters, such as plant age, have strong influence on bacterial response. The exact mechanisms responsible for the plant benefit in different plant-bacteria interactions are not clear, although some evidences point to resistance to diseases (Adhikari et al. 2001), increase in available nutrients (CaballeroMellado et al. 2004), biological nitrogen fixation (Baldani et al. 2000, Baldani and Baldani 2005) and bacterial auxin production (Costacurta and Vanderleyden 1995, Fuentes-Ramírez et al. 1993, James et al. 2002, Pedraza et al. 2004). To study the role of the multifactorial phytohormone auxin/IAA produced by $B$. kururiensis in our system, the transcriptional regulation of the exogenous auxin-reponsive promoter element DR5 (Scarpella et al. 2003) was monitored in rice roots from plantlets infected with the B. kururiensis. A specific and stronger activation of DR5-GUS was observed in the inoculated plantlets, suggesting that local increase in auxin perception could be due to bacterial auxin/IAA accumulation.

In summary, the results reported here show the ability of B. kururiensis to endophytically colonize rice plants. Additionally, B. kururiensis association confers 
beneficial effects on the growth and seed production of rice plants, possibly associated to differential auxin balance which enhances the rice plant development. Our findings are based on laboratory cultivation, which may not reproduce exactly the conditions of natural environment, but may indeed reflect the functional diversity of the Burkholderia species. Therefore, B. kururiensis arises as a potential tool for future agricultural applications, providing higher production yields, reduced input costs and negative environmental impact due to the use of nitrogen fertilizers.

\section{ACKNOWLEDGMENTS}

The authors are thankful to Prof. Thais Souto-Padron and Prof. Ulysses Garcia Casado Lins from the Electron Microscopy Sector of the Instituto de Microbiologia, Universidade Federal do Rio de Janeiro, for the use of transmission electron microscope FEI-Morgagni. This work was supported by grants from Conselho Nacional de Desenvolvimento Científico e Tecnológico (CNPq) and Fundação Carlos Chagas Filho de Amparo à Pesquisa do Estado do Rio de Janeiro (FAPERJ).

\section{RESUMO}

Burkholderia kururiensis é uma bactéria diazotrófica, originalmente isolada de um ambiente aquático poluído e apresenta alto nível de similaridade com a espécie endofítica " $B$. brasilensis" encontrada na planta de arroz. Este artigo demonstrou a habilidade de B. kururiensis colonizar endofiticamente plântulas de arroz, após esta bactéria ter sido inoculada na raiz das plantas. Esta capacidade foi confirmada pelo crescimento bacteriano em diferentes tecidos da planta, por microscopia eletrônica e pela análise do $16 \mathrm{~S}$ rADN. Observação por microscopia eletrônica das raízes, caule e folhas das plântulas de arroz inoculadas, revelou predominância da colonização de B. kururiensis na zona pilífera da raiz, demonstrando que a colonização endofítica inicia-se na endoderme, espalha-se pelo xilema, sendo esta a possível via para a bactéria alcançar as partes aéreas. A adição de uma fonte de nitrogênio, embora não tenha influenciado no crescimento bacteriano, foi um fator limitante para a colonização endofítica. Como a colonização endofítica mostrou-se diretamente associada ao aumento no desenvolvimento da planta, a produção do fitohormônio auxina/ácido 3indolacético pela $B$. kururiensis foi verificada utilizando uma plântula de arroz transgênica, contendo o repórter responsivo para auxina (DR5-GUS). Nossos resultados sugerem que a produção de auxina pela $B$. kururiensis é responsável pelo estímulo no desenvolvimento da planta verificado pela ativação do DR5GUS. Neste trabalho demonstramos, pela primeira vez, a habilidade de B. kururiensis colonizar endofiticamente a planta de arroz, promovendo tanto o aumento no crescimento da planta como a produção de sementes de arroz.

Palavras-chave: Burkholderia kururiensis, colonização, arroz, bactéria diazotrófica, auxina.

\section{REFERENCES}

Adhikari TB, Joseph CB, Yang G, Phillips DA AND NELSON LM. 2001. Evaluation of bacteria isolated from rice for plant growth promotion and biological control of seedling disease of rice. Can J Microbiol 47: 916-924.

Albrecht SL AND OKON Y. 1980. Cultures of Azospirillum. Methods Enzymol 69: 740-749.

Allen JRF, Greenway AM And Baker DA. 1979. Determinations of indole-3-acetic acid in xylem sap of Ricinus communis L. using mass fragmentography. Planta 144: 299-303.

Bacilio-Jiménez M, Aguilar-Flores S, del Valle MV, PÉreZ A, ZEPEdA A AND ZENTENo E. 2001. Endophytic bacteria in rice seeds inhibit early colonization of roots by Azospirillum brasilense. Soil Biol Biochem 33: $167-172$.

BALDANI JI AND BALDANI VLD. 2005. History on the biological nitrogen fixation research in graminaceous plants: special emphasis on the Brazilian experience. An Acad Bras Cienc 77: 549-579.

BALDANi VLD, Oliveira E, BALOTA E, BALdANi Ji, KirChHOF G AND Dobereiner J. 1997. Burkholderia brasilensis sp. nov., uma nova espécie de bactéria diazotrófica endofítica. An Acad Bras Cienc 69: 116.

BALDANI VLD, BALDANI JI AND DOBEREINER J. 2000. Inoculation of rice plants with the endophytic diazotrophs Herbaspirillum seropedicae and Burkholderia spp. Biol Fertil Soils 30: 485-491.

Barac T, Taghavi S, Borremans B, Provoost A, OEYEN L, COLPAERT JV, VANGRONSVELd J AND VAN DER LELIE D. 2004. Engineered endophytic bacteria improve phytoremediation of water-soluble, volatile, organic pollutants. Nat Biotechnol 22: 583-588.

BARRAQUio WL, REVILla L AND LADHA JK. 1997. Isolation of endophytic diazotrophic bacteria from wetland rice. Plant Soil 194: 15-24. 
BISWAS JC, LADHA JK AND DAZZO FB. 2000. Rhizobia inoculation improves nutrient uptake and growth of lowland rice. Soil Sci Soc Am J 64: 1644-1650.

Caballero-Mellado J, Martinez-Aguilar L, PareDes-VAldez G and Estrada-De-Los Santos P. 2004. Burkholderia unamae sp. nov., an $\mathrm{N}_{2}$-fixing rhizospheric and endophytic species. Int J Syst Evol Microbiol 54: 1165-1172.

Caballero-Mellado J, Onofre-Lemus J, EstradaDE-Los SAntos J AND Martinez-Aguilar L. 2007. The tomato rhizosphere, na environment rich in nitrogenfixing Burkholderia species with capabilities of interest for agriculture and bioremediation. Appl Environ Microbiol 73: 5308-5319.

Chen WM, JAmes EK, COENYE T, ChOU JH, BARrios E, de Faria SM, Elliot GN, Sheu Sy, Sprent JI AND VANDAMME P. 2006. Burkholderia mimosarum sp.nov., isolated from root nodules of Mimosa spp. from Taiwan and South America. Int J Syst Evol Microbiol 56: $1847-1851$.

Ciccillo F, Fiore A, Bevivino A, Dalmastri C, TABACCHIONI S AND CHIARINI L. 2002. Effects of two different application methods of Burkholderia ambifaria MCI 7 on plant growth and rhizospheric bacterial diversity. Environ Microbiol 4: 238-245.

Compant S, Reiter B, Sessitsch A, Nowak J, CléMENT C AND BARKA EA. 2005. Endophytic colonization of Vitis vinifera L. by plant growth-promoting bacterium Burkholderia sp. strain PsJN. Appl Environ Microbiol 71: 1685-1693.

Costacurta A And VAnderleyden J. 1995. Synthesis of phytohormones by plant-associated bacteria. Crit Rev Microbiol 21: 1-18.

Crozier A, Arruda P, Jasmin JM, Monteiro AM AND SANDBERG G. 1988. Analysis of indole-3-acetic acid and related indoles in culture medium from Azospirillum lipoferum and Azospirillum brasilense. Appl Environ Microbiol 54: 2833-2837.

Dong Z, McCully ME And Canny MJ. 1997. Does Acetobacter diazotrophicus live and move in the xylem of sugarcane stems anatomical and physiological data. Ann Bot 80: 147-158.

El-Banna N And Winkelmann G. 1998. Pyrrolnitrin from Burkholderia cepacia: antibiotic activity against fungi and novel activities against streptomycetes. J Appl Microbiol 85: 69-78.

ELmann A. 1977. The Van Urk-Salkowski reagent-a sen- sitive and specific chromatogenic reagent for silica gel thin-layer chromatographic detection and identification of indole derivatives. J Chromatogr 132: 267-276.

Estrada-De los Santos P, Bustillos-Cristales R AND Caballero-Mellado J. 2001. Burkholderia, a genus rich in plant-associated nitrogen fixers with wide environmental and geographic distribution. Appl Environ Microbiol 67: 2790-2798.

FuENTES-RAMÍREZ LE, JiMENEZ-SALGADO T, ABARCAOCAmpo IR and Caballero-Mellado J. 1993. Acetobacter diazotrophicus, an indoleacetic acid producing bacterium isolated from sugarcane cultivars of Mexico. Plant Soil 154: 145-150.

Gillis M, Trân VAn V, BARdin R, Goor M, HebBar P, Willems A, Segers P, Kersters K, Heulin T AND Fernandez MP. 1995. Polyphasic taxonomy in the genus Burkholderia leading to an emended description of the genus and proposition of Burkholderia vietnamiensis sp. nov. for N2-fixing isolates from rice in Vietnam. Int J Syst Evol Microbiol 45: 274-289.

Goris J, De Vos P, Caballero-Mellado J, Park J, FAlsen E, Quensen III JF, TIEDJE JM AND VANDAMME P. 2004. Classification of the biphenyl- and polychlorinated biphenyl-degrading strain LB400T and relatives as Burkholderia xenovorans sp. nov. Int J Syst Evol Microbiol 54: 1677-1681.

Govindarajan M, Balandreau J, Kwon S-W, WeON H-Y AND LAKSHMINARASIMHAN C. 2008. Effects of the inoculation of Burkholderia vietnamensis and related endophytic diazotrophic bacteria on grain yield of rice. Microb Ecol 55: 21-37.

HOAGLAND DR. 1975. Mineral nutrition. In: LABOVITCH A, Anderson-Prouty N And Ghosheh S (Eds), Laboratory Experiments in Plant Physiology. Macmillan Publishing Co. Inc, New York, NY, p. 129-134.

Hurek T, Reinhold-Hurek B, van Montagu M and Kellenberger E. 1994. Root colonization and systemic spreading of Azoarcus sp. strain BH72 in grasses. J Bacteriol 176: 1913-1923.

JAMES EK AND OLIVARES FL. 1998. Infection and colonization of sugarcane and other graminaceous plants by endophytic diazotrophs. Crit Rev Plant Sci 17: 77-119.

JAMES EK, REIS VM, OLIVARES FL, BALDANI JI AND DOBEREINER J. 1994. Infection of sugarcane by the nitrogen-fixing bacterium Acetobacter diazotrophicus. J Exp Bot 45: 757-766.

JAMES EK, OLIVARES FL, BALDANI JI AND DOBEREINER 
J. 1997. Herbaspirillum, an endophytic diazotroph colonizing vascular tissue in leaves of Sorghum bicolor L. Moench. J Exp Bot 48: 785-797.

JAMES EK, GyAneshWAR P, Mathan N, BARRAQuio WL, REDDY PM, IANETTA PPM, OLIVARES FL AND LADHA JK. 2002. Infection and colonization of rice seedlings by the plant growth-promoting bacterium Herbaspirillum seropedicae Z67. Mol Plant Microbe Interact 15: 894-906.

Kuklinsky-Sobral J, Araújo WL, Mendes R, GeRAldi IO, Pizzirani-Kleiner AA ANd Azevedo JL. 2004. Isolation and characterization of soybean-associated bacteria and their potential for plant growth promotion. Environ Microbiol 6: 1244-1251.

LeVine MM, Nataro JP, Karch H, Baldani MM, KAPER JB AND BLACK RE. 1985. The diarrhead response of humans to some classic serotypes of enteropathogenic Escherichia coli is dependent on a plasmid encoding an enteroadhesiveness factor. J Infection Dis 152: $550-559$.

Maes M, Gaberna P And CRepel C. 1996. Identification and sensitive endophytic detection of the fire blight pathogen Erwinia amylovora with $23 \mathrm{~S}$ ribosomal DNA sequences and the polymerase chain reaction. Plant Pathol 45: 1139-1149.

Marin VA, TeIXeira KRS AND BALDANi JI. 2003. Characterization of amplified polymerase chain reaction $g \ln B$ and nifH gene fragments of nitrogen-fixing Burkholderia species. Lett Appl Microbiol 36: 77-82.

Mattos KA, Todeschini AR, Heise N, Jones C, Previato JO And MendonçA-Previato L. 2005. Nitrogen-fixing bacterium Burkholderia brasilensis produces a novel yersiniose A containing O-polysaccharide. Glycobiology 15: 313-321.

Muñoz-Rojas J And Caballero-Mellado J. 2003. Population dynamics of Gluconacetobacter diazotrophicus in sugarcane cultivars and its effect on plant growth. Microbiol Ecol 46: 454-464.

Murashige T And Skoog F. 1962. A revised medium for rapid growth and bioassays with tobacco tissue culture. Physiol Plant 15: 473-497.

MuthuKumarasamy R, REVATHI G AND LogANATHAM P. 2002. Effect of inorganic $\mathrm{N}$ on the population, in vitro colonization and morphology of Acetobacter diazotrophicus (syn. Gluconacetobacter diazotrophicus). Plant Soil 243: 91-102.

Muthukumarasamy R, Govindarajan M, Vadivelu
M AND Revathi G. 2006. N-fertilizer saving by the inoculation of Gluconacetobacter diazotrophicus and Herbaspirillum sp. in micropropagated sugarcane plants. Microbiol Res 161: 238-245.

Oliveira ALM, Urquiaga S, Dobereiner J AND BaLDANI JI. 2002. The effect of inoculating endophytic $\mathrm{N}_{2}$ fixing bacteria on micropropagated sugarcane-plants. Plant Soil 242: 205-215.

Pedraza RO, Ramirez-Mata A, Xiqui ML and BaÇA BE. 2004. Aromatic amino acid aminotransferase activity and indole-3-acetic acid production by associative nitrogen-fixing bacteria. FEMS Microbiol Lett 233: 15-21.

Perin L, Martinez-Aguilar L, Castro-Gonzalez R, Estrada-De los Santos P, Cabellos-Avelar T, Guedes HV, Reis VM AND CABAllero-Mellado J. 2006. Diazotrophic Burkholderia species associated with field-grown maize and sugarcane. Appl Environ Microbiol 72: 3103-3110.

Purcell AH AND Hopkins DL. 1996. Fastidious xylemlimited bacterial plant pathogens. Annu Rev Phytopathol 34: 131-151.

RAMEy BE, Koutsoudis M, von Bodman SB AND FUQUA C. 2004. Biofilm formation in plant microbe associations. Curr Op Microbiol 7: 602-609.

Reinhold B, Hurek T, NiEMAnN EG AND FENDRiK I. 1986. Close association of Azospirillum and diazotrophic rods with different root zones of kallar grass. Appl Environ Microbiol 52: 520-526.

REIS VM ET AL. 2004. Burkholderia tropica sp.nov., a novel nitrogen-fixing, plant-associated bacterium. Int J Syst Evolut Microbiol 54: 2155-2162.

Rodrigues Neto J, Malavolta Jr VA and Victor O. 1986. Meio simples para isolamento e cultivo de Xanthomonas campestris pv. citri Tipo B. Sum Phytol 2: 16.

Roncato-Maccari LDB, Ramos HJo, Pedrosa Fo, Alquini Y, Chubatsu ls, Yates MG, Rigo LU, STEFFENS MBR AND SouzA ES. 2003. Endophytic Herbaspirillum seropedicae expresses nif genes in graminous plants. FEMS Microbiol Ecol 1519: 1-9.

Rosenblueth M And Martinez-Romero E. 2006. Bacterial endophytes and their interactions with hosts. Mol Plant Microbe Interact 19: 827-837.

Sabaratnam S And Beattie GA. 2003. Differences between Pseudomonas syringae pv. syringae B728a and Pantoea agglomerans BRT98 in epiphytic and endophytic colonization of leaves. Appl Environ Microbiol 69: 1220-1228. 
Santos AV, Dillon RJ, Dillon VM, Reynolds SE AND SAMUELS RI. 2004. Occurrence of the antibiotic producing bacterium Burkholderia sp. in colonies of the leaf-cutting ant Atta sexdens rubropilosa. FEMS Microbiol Lett 239: 319-323.

Scarpella E, Rueb S AND MeiJer AH. 2003. The RADICLELESS1 gene is required for vascular pattern formation in rice. Development 130: 645-658.

SESSITSCH A ET AL. 2005. Burkholderia phytofirmans sp.nov., a novel plant-associated bacterium with plantbeneficial properties. Int J Syst Evol Microbiol 55: 1187-1192.

SEVIlla M, BurRis RH, GunAPALA N AND KENNEDy C. 2001. Comparison of benefit to sugarcane plant growth and ${ }^{15} \mathrm{~N}_{2}$ incorporation following inoculation of sterile plants with Acetobacter diazotrophicus wild-type and Nifmutant strains. Mol Plant Microbe Interact 14: 358-366.

TAN Z, HureK T AND Reinhold-Hurek B. 2003. Effect of $\mathrm{N}$-fertilization, plant genotype and environmental conditions on nifH gene pools in roots of rice. Environ Microbiol 5: 1009-1015.
Tomita K, Kitsuwa T, Murayama T AND NAKAMURA T. 1987. Identification of indol-3-acetic acid in Neurospora crassa. Agric Biol Chem 59: 2633-2634.

TrÂn VAn V, Berge O, Ngo Ke S, Balandreau J AND HEULIN T. 2000. Repeated beneficial effect of rice inoculation with a strain of Burkholderia vietnamiensis on early and late yield components in low fertility sulphate acid soils of Vietnam. Plant Soil 218: 273-284.

WANG JL, MAO ZY, HAN LP AND QIAN Y. 2004. Bioremediation of quinoline-contaminated soil using bioaugmentation in slurry-phase reactor. Biomed Environ Sci 17: 187-195.

Zhang H, Hanada S, Shigematsu T, Shibuya K, Kamagata Y, Kanagawa T AND Kurame R. 2000. Burkholderia kururiensis sp.nov., a trichloroethylene (TCE)-degrading bacterium isolated from an aquifer polluted with TCE. Int J Syst Evol Microbiol 50: 743-749. 